\title{
PHENOLOGY OF THE NEW ZEALAND FLOWER THRIPS (THRIPS OBSCURATUS) IN TWO VINEYARDS
}

\author{
K. SCHMIDT ${ }^{1}$, D.A.J. TEULON ${ }^{2}$ and M.V. JASPERS ${ }^{1}$ \\ ${ }^{I}$ National Centre for Advanced Bio-Protection Technologies, PO Box 84, \\ Lincoln University, Canterbury, New Zealand \\ ${ }^{2}$ Crop \& Food Research, Private Bag 4704, Christchurch, New Zealand
}

Corresponding author: schmidtk@lincoln.ac.nz

\begin{abstract}
Adult thrips, especially New Zealand flower thrips (Thrips obscuratus) were monitored with white water traps at Canterbury House Vineyard, near Waipara in North Canterbury, and Neudorf Vineyard, near Motueka, from spring to autumn in the 2003/04 and 2004/05 seasons. Traps were placed within the grapevine rows $140 \mathrm{~cm}$ above ground. The largest populations of airborne thrips, of which around $90 \%$ were T. obscuratus, occurred during the five weeks coinciding with grapevine flowering. In 2003/04 additional traps were placed at 80 and $15 \mathrm{~cm}$ above ground, but only at Canterbury House Vineyard, and T. obscuratus were more abundant in the highest traps than in the lower ones. Sampling of flower bunches revealed that $T$. obscuratus were more abundant in the later flowering 'Sauvignon blanc' than 'Riesling' grapevines. Overall, more thrips were trapped in Neudorf than Canterbury House vineyard, which may be attributed to the greater diversity of flowering sources outside the vineyards.
\end{abstract}

Keywords: Thrips obscuratus, water traps, vineyards, populations, phenology, overwintering sites, alternative host plants.

\section{INTRODUCTION}

The endemic New Zealand flower thrips (Thrips obscuratus (Crawford)), is one of the most common thrips species found in New Zealand (Walker 1985). Originally an inhabitant of the endemic host plants, it has successfully colonised numerous plants introduced into New Zealand (Teulon \& Penman 1990). Adults and larvae feed by sucking the contents from soft plant tissues, pollen grains, nectar and some ripe fruits. Thrips obscuratus is considered a pest of stonefruit (Teulon \& Penman 1995; McLaren et al. 1997). In spring, feeding by adults and larvae on nectarine ovaries and small fruits results in irregularly shaped blocks of russets (McLaren 1992), fine scar lines and fruit distortion, a symptom which has also been reported in young passionfruit (May 1963). The adult $T$. obscuratus also infest nectarine and peach fruit at harvest where they feed and oviposit. Thrips obscuratus adults and larvae can be found throughout the year where host plants, such as gorse Ulex europaeus L, are available (McLaren 1995; Teulon \& Penman 1996).

Thrips obscuratus was first described by Crawford (1941) from grape flowers and large populations of them have recently been reported in New Zealand vineyards (Marroni et al. 2002; Marroni Bada 2003). It appears to invade grape flowers in spring from nearby flower sources or other overwintering sites (Marroni Bada 2003; Teulon et al. 2005). To date $T$. obscuratus in wine-producing vineyards have not been reported to lead directly to yield losses, but in recent years some viticulturists have expressed concern about the damage they cause on grapes, especially the severe scarring associated with high thrips numbers at flowering (P. Gladstone, pers. comm.; K. Olsson, pers. comm.).

So far there are no studies that report the phenology of T. obscuratus in vineyards. Therefore, the aim of this study was to determine the relative abundance of T. obscuratus 
in vineyards from spring to autumn and its infestation levels on flower bunches in two different regions in the South Island of New Zealand. The information gathered from this study will help to establish whether T. obscuratus should be considered a pest on grapevines in the South Island.

\section{MATERIALS AND METHODS}

Trials were conducted at Canterbury House Vineyard in Waipara, North Canterbury, and Neudorf Vineyard near Motueka in the Nelson region. Canterbury House Vineyard has about 100 ha and consists of several blocks of the grapevine varieties 'Pinot Noir', 'Merlot', 'Riesling', 'Chardonnay', 'Sauvignon blanc' and 'Pinot gris'. All sampling at Canterbury House Vineyard described below was done in one 'Riesling' block and the adjacent 'Sauvignon blanc' block in the middle of the vineyard. Neudorf Vineyard has about 50 ha of mainly the grapevine variety 'Pinot noir', but also a few blocks of 'Chardonnay' and one block of 'Riesling' and 'Pinot gris'. All sampling of this vineyard took place in the one 'Riesling' block in the middle of the vineyard. The numbers and species of thrips within the vineyard were estimated for 2003/04 and 2004/05 using flower and water trap samples.

\section{Flower sampling}

At full bloom, 10 flower bunches of the grapevine varieties 'Riesling' and 'Sauvignon blanc', at Canterbury House Vineyard, and of 'Riesling' at Neudorf Vineyard, were randomly chosen in the selected blocks, cut and carefully placed into new re-sealable plastic bags to retain the thrips already on the bunch. These bunches were placed in a freezer $\left(-20^{\circ} \mathrm{C}\right)$ to kill all thrips and store them until counting. After counting, a sub-sample of $10-20 \%$ of the thrips of each sample was taken and mounted onto microscope slides for species identification, using descriptions and keys from Mound \& Walker (1982) and Mound \& Kibby (1998).

\section{Sampling by water traps}

Water traps were open, white plastic containers $(170 \times 170 \times 85 \mathrm{~mm})$ placed on metal posts within the grapevine row. In the first field season (2003/2004) at the Canterbury House field site in Waipara, three different heights were used for the traps: six traps each at $15 \mathrm{~cm}, 80 \mathrm{~cm}$ (below grapevine canopy) and $140 \mathrm{~cm}$ (in the middle of the grapevine canopy) above ground. The different heights gave an indication of where within the grapevine rows thrips would be mostly found during the season. The traps were placed in the vineyard on 13 November 2003 in six rows within the middle of the 'Riesling' block. Each selected row contained three traps of each height, which were placed at least $30 \mathrm{~m}$ apart from each other and none closer to the end of the row than $10 \mathrm{~m}$. At the Neudorf Vineyard field site, 6 water traps were set up at only $140 \mathrm{~cm}$ above ground level on 10 December 2003. Two rows were selected in the 'Riesling' block of the vineyard and three traps were placed in each row at least $30 \mathrm{~m}$ apart from each other and none closer to the end of the row than $10 \mathrm{~m}$. Sampling ended with the grape harvest on 1 April at Canterbury House Vineyard and on 24 March 2004 at Neudorf Vineyard.

In the second season $(2004 / 2005)$ six water traps were placed at both field sites right next to the vine canopy at $140 \mathrm{~cm}$ above ground in two selected rows of the 'Riesling' block (three traps in each). They were set up on 24 November 2004 for Canterbury House Vineyard and on 2 December 2004 for Neudorf Vineyard, with sampling ending with the grape harvest on 14 April and 7 April 2005 respectively. In both seasons, all water traps contained ca 2 litres of water, with 5 drops of detergent, to break the surface tension so that captured insects would sink to the bottom of the traps, and ca $5 \mathrm{ml}$ of propylene glycol, to prevent fungal and algal growth in the traps. All traps were emptied fortnightly through a sieve and the strained contents of each trap were stored in $120 \mathrm{ml}$ specimen jars filled with $70 \%$ ethanol at $10^{\circ} \mathrm{C}$. After counting the thrips in each sample, a sub-sample of $10-20 \%$ from each sample was taken and mounted onto microscope slides for species identification, using descriptions and keys from Mound \& Walker (1982) and Mound \& Kibby (1998). The proportion of each sub-sample that was made up of T. obscuratus and other thrips species was determined for each sampling time and locality. 


\section{Data analysis}

Data from the flower bunches from each variety $\mathrm{x}$ site combination were used to calculate $95 \%$ confidence intervals for the mean number of T. obscuratus per flower bunch. Confidence intervals that do not overlap indicated a difference in the mean number of T. obscuratus per flower bunch.

\section{Flower sampling}

\section{RESULTS}

In both years, mean numbers of T. obscuratus per 'Riesling' flower bunch were greater in Neudorf Vineyard than in the Canterbury House Vineyard (Table 1). Mean numbers of T. obscuratus in 'Sauvignon blanc', which was sampled in Canterbury House Vineyard only, were higher than for 'Riesling' in 2003 but not in 2004.

\section{TABLE 1: Mean number of T. obscuratus per flower bunch at Neudorf Vineyard and Canterbury House Vineyard in two seasons.}

\begin{tabular}{llrllccc}
\hline & & \multicolumn{2}{c}{ Riesling } & & \multicolumn{2}{c}{ Sauvignon Blanc } \\
\cline { 3 - 4 } \cline { 7 - 8 } Year & Field site & Mean & $95 \%$ CI $^{1}$ & & Mean & $95 \%$ CI \\
\hline 2003 & Neudorf & 72.8 & $(54.8 ; 90.8)$ & & - & - \\
2003 & Canterbury House & 16.4 & $(13.1 ; 19.7)$ & & 52.9 & $(42.7 ; 63.1)$ \\
2004 & Neudorf & 107.6 & $(60.9 ; 154.3)$ & & - & - \\
2004 & Canterbury House & 22.1 & $(14.1 ; 30.2)$ & & 27.8 & $(16.2 ; 39.4)$ \\
\hline
\end{tabular}

${ }^{1}$ Confidence interval.

\section{Sampling by water traps}

In the first field season at the Canterbury House Vineyard field site, the mean number of all thrips species caught at all three heights increased between the first and second sampling times, which occurred during the flowering period of the grapevines (Fig. 1a). After that the numbers declined at almost the same rate as they increased, and were very low by the end of the season. On the first three sampling times, the numbers of all thrips caught were highest in the $140 \mathrm{~cm}$ traps, which were positioned next to the vine canopy and the flower bunches, and lowest in the $15 \mathrm{~cm}$ traps. Except during full bloom, T. obscuratus made up only a small proportion $(\leq 50 \%$ of all thrips caught in the traps). Most T. obscuratus were captured in the $140 \mathrm{~cm}$ and $80 \mathrm{~cm}$ traps with only $50 \%$ or fewer in the lowest traps (Fig. 1b).

The overall dynamics of thrips populations caught in water traps next to the grapevine canopy at $140 \mathrm{~cm}$ above ground was quite similar at both field sites and in the two seasons (Figs 2a \& 2b). Most thrips were caught in water traps during full bloom and numbers declined from there on until sampling was stopped at harvest, which was two weeks later in the second season. The decline of thrips numbers was faster at Neudorf Vineyard than at Canterbury House Vineyard. In the first season (2003/04) at Neudorf Vineyard, the start of the flowering period was slightly missed due to the late start of the project in this vineyard (Fig. 2b).

At both field sites and in both seasons, mean percent of T. obscuratus of all thrips caught in the water traps was highest at full bloom. In 2004/05 the mean percent of T. obscuratus was higher than in 2003/04 at both field sites (Figs 2a \& 2b). At Canterbury House Vineyard, T. obscuratus made up around $50 \%$ or more of all thrips caught in the traps in 2004/05, whereas in the previous year proportions fell to $20 \%$ during the summer and slowly rose up again to approximately $50 \%$ by harvest (Fig. 2a). At Neudorf Vineyard the percentage of T. obscuratus of all thrips caught in the traps dropped to around $20 \%$ during the summer of both seasons and stayed low until harvest (Fig. 2b). 

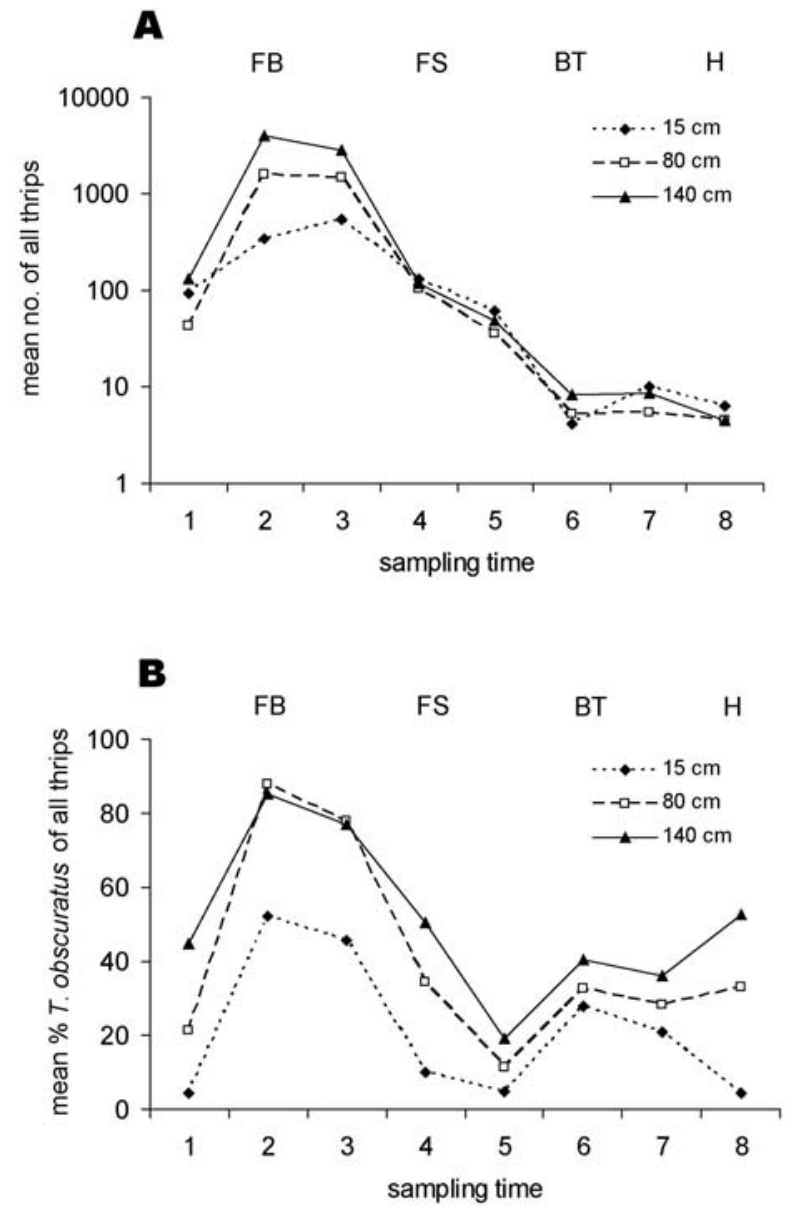

FIGURE 1: (A) Mean number of all thrips species (logarithmic axis) and (B) mean percent of $T$. obscuratus of all thrips captured. Data are for three different heights of water traps during 2003/04 at Canterbury House Vineyard. Physiological stages of the grapevine are indicated by $\mathrm{FB}=$ full bloom, $\mathrm{FS}=$ fruit set, $\mathrm{BT}=$ =berry touch and $\mathrm{H}=$ =harvest. 


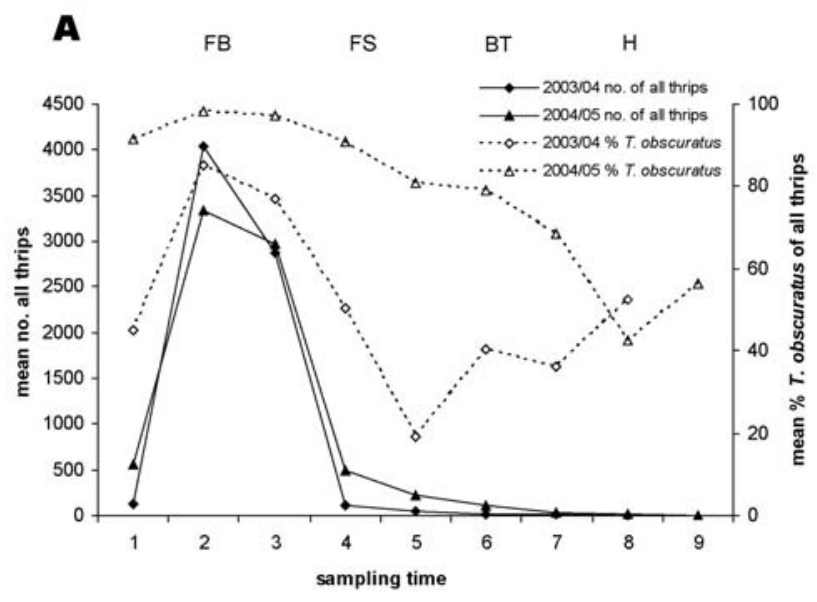

B

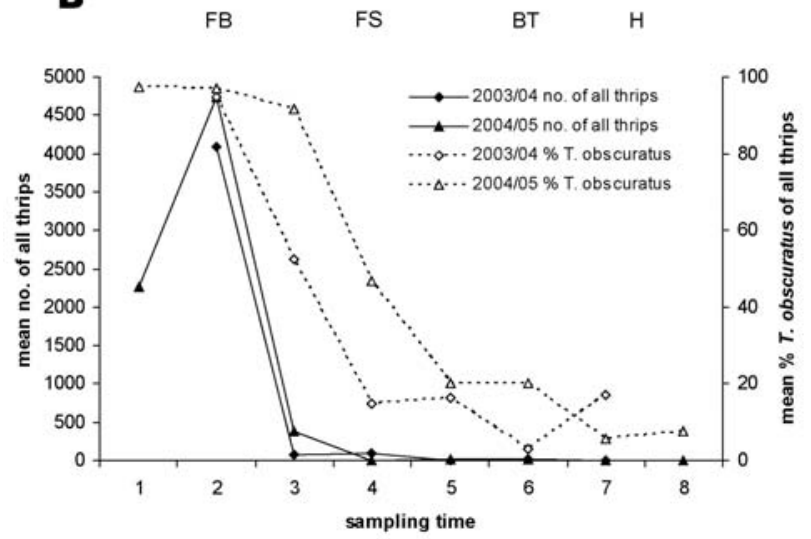

FIGURE 2: Mean number of all thrips and mean percent $T$. obscuratus of all thrips captured in water traps set at $140 \mathrm{~cm}$ above ground in two seasons at (A) Canterbury House and (B) Neudorf Vineyards. Physiological stages of the grapevine are indicated by $\mathrm{FB}=$ full bloom, $\mathrm{FS}=$ fruit set, BT=berry touch and $\mathbf{H}=$ harvest. 
Other adult thrips species identified at both field sites in the water traps were mostly Limothrips cerealium Haliday, Thrips australis Bagnall and some species from the sub-order Tubulifera. Only low numbers of thrips larvae were detected on flowers and in water traps (K. Schmidt, unpubl. data).

\section{DISCUSSION}

The lower number of T. obscuratus on flower bunches in 'Riesling' compared to 'Sauvignon blanc' (Table 1) might not be a true effect as a difference was only seen in one of the sampling years. Any differences observed may have been due to a time effect rather than a true variety effect, since 'Riesling' came into flower approximately a week before 'Sauvignon blanc' at the time when aerial populations of T. obscuratus were building up rapidly (sampling times 1 and 2 in Fig. 1a \& Fig. 2a).

Although the occurrence and seasonal flight patterns of T. obscuratus during the season have been reported in stone and pipfruit (McLaren 1992, 1995; Teulon \& Penman 1994, 1995), little is known about its phenology in vineyards. In this study, the flight patterns of adult $T$. obscuratus throughout the season were similar to those reported by Teulon \& Penman (1994) on stonefruit, who found that numbers increased during the flowering period and declined afterwards. However, the relatively high numbers of $T$. obscuratus larvae they found on stonefruit flowers following the peak number of adults caught were not repeated here (Teulon \& Penman 1994). Numbers of T. obscuratus adults caught in water traps in this study increased rapidly during the flowering period, but only low numbers of larvae were detected on flowers and water traps, which might indicate that the high number of adults found in the vineyards did not result from breeding populations within the grape flowers but most likely by emigration from sources outside the vineyard (Teulon et al. 2005).

The decreasing numbers of T. obscuratus caught in the vineyards after flowering were probably because only grape flowers provided sufficient food sources for these insects, which might have been emigrating the vineyard when these food sources deteriorated. Although T. obscuratus mainly feed on flowers, consuming mostly nectar and pollen, they also feed on ripe nectarine and peaches (McLaren 1992; Teulon \& Penman 1994). However, during the present study they were not observed feeding on ripe grape berries. The few thrips found throughout the season were probably surviving on the flowering weeds found in and around the vineyards.

The widespread distribution of T. obscuratus can be attributed to its long distance spread by wind (McLaren 1995) and to the large areas of introduced weeds, such as gorse, broom and lupin, which have been recorded as common host plants for T. obscuratus (Teulon \& Penman 1990) and possibly act as a source of these insects in early spring. Native host plants of $T$. obscuratus probably do not play an important role as immigration sources, since most of them have been cleared from the agricultural landscape around most vineyards. Thrips obscuratus densities in the grapevines may therefore be influenced by a number of factors, including availability and proximity of overwintering hosts, the weather and the overall landscape structure. The numbers of all thrips, including $T$. obscuratus, caught in the water traps and numbers of $T$. obscuratus in the flower bunches were higher at Neudorf Vineyard than at Canterbury House Vineyard, possibly because the Motueka region, in which Neudorf Vineyard is located, has a diverse natural and crop flora. It has forested areas as well as fruit orchards, hop fields, pasture and home gardens, which undoubtedly provide an almost year-round source of flowering plants to act as a food source. Observations of the different types of weeds and crops adjacent to Neudorf Vineyard indicated a wide variety of possible overwintering and alternative host plants for T. obscuratus (K. Schmidt, unpubl. data). Additionally, the weather at Neudorf Vineyard is much warmer and has a higher humidity throughout the year than in the Waipara valley, where Canterbury House Vineyard is located. The Waipara valley contains mostly pasture, and broom and gorse grow on the hillsides. 


\section{REFERENCES}

Crawford JC 1941. A new Isoneurothrips from New Zealand (Thysanoptera: Thripidae). Proceedings of the Entomological Society of Washington 43: 63-64.

Marroni Bada MV 2003. The influence of flower-feeding thrips on grape bunch rot. MSc. Thesis, Lincoln University, Lincoln, New Zealand.

Marroni MV, Teulon DAJ, Scott RR, Jaspers MV 2002. Thrips incidence on grape flowers in New Zealand. New Zealand Plant Protection 55: 438.

May BM 1963. New entomological records. New Zealand Entomologist 3: 44-53.

McLaren GF 1992. Thrips on nectarines in the spring. Proceedings of the 45th New Zealand Plant Protection Conference: 111-115.

McLaren GF 1995. Ecology of New Zealand Flower Thrips Thrips obscuratus (Crawford) in central Otago. Australian and New Zealand Thrips Workshop. Pp. 4-7.

McLaren GF, Fraser JA, McDonald RM 1997. The feasibility of hot water disinfestation of summerfruit. Proceedings of the 50th New Zealand Plant Protection Conference: 425-430.

Mound LA, Kibby G 1998. Thysanoptera, an identification guide. 2nd edn. CAB International, New York. 70 pp.

Mound LA, Walker AK 1982. Fauna of New Zealand. Science Information Division, DSIR, Wellington. $113 \mathrm{pp}$.

Teulon DAJ, Marroni MV, Nielsen M-C 2005. Do high country weeds act as a nursery for invasive thrips species in spring? New Zealand Plant Protection 58: 324.

Teulon DAJ, Penman D 1990. Host records for the New Zealand flower thrips (Thrips obscuratus (Crawford) Thysanoptera: Thripidae). New Zealand Entomologist 13: 46-51.

Teulon DAJ, Penman D 1994. Phenology of the New Zealand flower thrips, Thrips obscuratus (Crawford) (Thysanoptera: Thripidae) on nectarine and peach flowers. New Zealand Entomologist 17: 70-77.

Teulon DAJ, Penman D 1995. Thrips obscuratus: A pest of stonefruit in New Zealand. In: Thrips biology and management. Parker BL, Skinner M, Lewis T ed. Plenum Press, New York. Pp. 101-104.

Teulon DAJ, Penman D 1996. Thrips (Thysanoptera: Thripidae) seasonal flight activity and infestation of ripe stonefruit in Canterbury, New Zealand. Journal of Economic Entomology 89: 722-734.

Walker AK 1985. Flower thrips in New Zealand. Horticulture News 7: 6-7. 